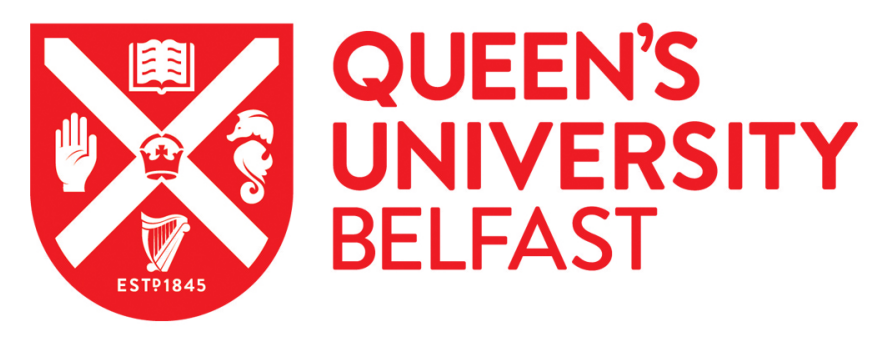

\title{
Knowledge and acceptance of Human Papillomavirus (HPV) and HPV vaccination in adolescent boys worldwide: a systematic review
}

Prue, G., Shapiro, G., Maybin, R., Santin, O., \& Lawler, M. (2016). Knowledge and acceptance of Human Papillomavirus (HPV) and HPV vaccination in adolescent boys worldwide: a systematic review. Journal of Cancer Policy, 1-5. https://doi.org/10.1016/j.jcpo.2016.09.009

Published in:

Journal of Cancer Policy

Document Version:

Peer reviewed version

Queen's University Belfast - Research Portal:

Link to publication record in Queen's University Belfast Research Portal

Publisher rights

(C) 2016 Elsevier Ltd. All rights reserved.

This is an open access article published under a Creative Commons Attribution-NonCommercial-NoDerivs License

(https://creativecommons.org/licenses/by-nc-nd/4.0/), which permits distribution and reproduction for non-commercial purposes, provided the author and source are cited.

\section{General rights}

Copyright for the publications made accessible via the Queen's University Belfast Research Portal is retained by the author(s) and / or other copyright owners and it is a condition of accessing these publications that users recognise and abide by the legal requirements associated with these rights.

Take down policy

The Research Portal is Queen's institutional repository that provides access to Queen's research output. Every effort has been made to ensure that content in the Research Portal does not infringe any person's rights, or applicable UK laws. If you discover content in the Research Portal that you believe breaches copyright or violates any law, please contact openaccess@qub.ac.uk. 


\section{Accepted Manuscript}

Title: Knowledge and acceptance of Human Papillomavirus (HPV) and HPV vaccination in adolescent boys worldwide: a systematic review.

Author: Gillian Prue Gilla Shapiro Ruth Maybin Olinda Santin Mark Lawler

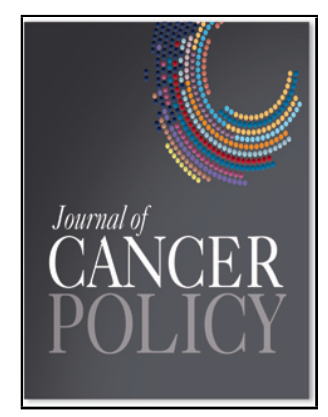

PII: S2213-5383(16)30029-7

DOI:

Reference: http://dx.doi.org/doi:10.1016/j.jcpo.2016.09.009

To appear in:

Received date: 28-6-2016

Accepted date: $\quad$ 25-9-2016

Please cite this article as: Gillian Prue, Gilla Shapiro, Ruth Maybin, Olinda Santin, Mark Lawler, Knowledge and acceptance of Human Papillomavirus (HPV) and HPV vaccination in adolescent boys worldwide: a systematic review., Journal of Cancer Policy http://dx.doi.org/10.1016/j.jcpo.2016.09.009

This is a PDF file of an unedited manuscript that has been accepted for publication. As a service to our customers we are providing this early version of the manuscript. The manuscript will undergo copyediting, typesetting, and review of the resulting proof before it is published in its final form. Please note that during the production process errors may be discovered which could affect the content, and all legal disclaimers that apply to the journal pertain. 
Knowledge and acceptance of Human Papillomavirus (HPV) and HPV vaccination in adolescent boys worldwide: a systematic review.

Gillian Prue $^{\mathrm{a}}$, Gilla Shapiro ${ }^{\mathrm{b}}$, Ruth Maybin ${ }^{\mathrm{c}}$, Olinda Santin ${ }^{\mathrm{a}}$, Mark Lawler ${ }^{\mathrm{d}}$

aSchool of Nursing and Midwifery, Medical Biology Centre, Queen's University Belfast, 97 Lisburn Road, Belfast, BT9 7BL, UK

${ }^{b}$ Department of Psychology, McGill University, 1205 Dr. Penfield Avenue, Montreal QC H3A 1B1, Canada.

'School of Medicine, Dentistry and Biomedical Sciences, Whitla Medical Building, Queen's University Belfast, 97 Lisburn Road, Belfast, BT9 7BL, UK

'School of Medicine, Dentistry and Biomedical Sciences, Queen's University Belfast, Centre for Cancer Research and Cell Biology, 97 Lisburn Road, Belfast, BT9 7BL, UK.

\section{Corresponding Author}

Gillian Prue, $\mathrm{PhD}$

Room 06.315

School of Nursing and Midwifery

Medical Biology Centre

Queen's University Belfast

Belfast

Northern Ireland

BT9 7BL

g.prue@qub.ac.uk 


\section{HIGHLIGHTS}

- Globally adolescent males have poor knowledge of HPV and HPV vaccination.

- Adolescent male knowledge of HPV is lower than their female peers.

- High knowledge of HPV is not always predictive of HPV vaccine acceptance.

- Standardised measures of HPV knowledge/acceptance used longitudinally are needed.

- Imperative to identify methods of increasing male adolescent awareness of HPV.

\section{ABSTRACT}

Aim: To determine HPV and HPV vaccine awareness, knowledge and acceptance in male adolescents worldwide.

Methods: A mixed methods systematic review was conducted. In accordance with PRISMA guidelines, relevant literature was identified through an electronic database search using specified keywords from inception to September 2015. Non-interventional studies presented in English that assessed HPV knowledge and provided data on male adolescents were included. If available, data on HPV and HPV vaccine perceptions, attitudes and/or HPV vaccine acceptance were also extracted. All studies were critically appraised to provide an indication of methodological quality. Results were compiled using a convergent synthesis.

Results: 22 papers were included. The majority of studies were cross-sectional and conducted in the US and Europe. Across continents, regardless of a country's HPV vaccination programme status, boys' knowledge of HPV and/or HPV vaccination was generally low to moderate and significantly lower than female knowledge or awareness. There was a disagreement in the association of knowledge and vaccine acceptance, with higher knowledge not always being predictive of acceptance.

Conclusions: Comparison and synthesis of research concerning HPV knowledge and attitudes was made difficult due to the lack of universal definition of vaccine acceptance, and no universally accepted tool for its measurement or for the measurement of HPV knowledge. It is imperative that future research utilises consistent measures of HPV knowledge and attitudes to facilitate interpretation and comparison across studies internationally. Prospective longitudinal studies would be more informative providing data on factors that influenced the move from vaccine intention to uptake.

\section{KEYWORDS}

HPV; Human papillomavirus; Systematic review; adolescents; men's health; cancer; cancer prevention; vaccination 


\section{INTRODUCTION}

Human papillomavirus (HPV) is the most common sexually transmitted infection worldwide [1]. HPV infection is well-recognised as the causative agent in all cervical cancers; with two types (16/18) underpinning $70 \%$ of cervical cancer cases worldwide [2]. HPV is also linked to genital, anal [3], and oropharyngeal cancer (OPC) [4]. Approximately 95\% of anal cancers are caused by HPV; $65 \%$ of vaginal cancers; $50 \%$ of vulvar cancers, and $35 \%$ of penile cancers [5]. OPC shows a regional/socio-economic variation; in comparison to the highincome areas of North America, Northern and Western Europe, Australia and Japan with a prevalence range of $39-56 \%$, the rest of the world appears to have a lower prevalence (13$38 \%$ ) [6]. In the United States (US), it is predicted that the number of HPV-related OPCs diagnosed per year will soon surpass the annual number of cervical cancer cases [7]. Infection with low-risk HPV (6/11) are also implicated in the development of genital warts [8].

Despite the impact of HPV on both sexes, few countries have implemented a vaccination programme for both adolescent boys and girls. Australia was the first country to initiate government-funded universal HPV vaccination, and began including boys in a national school-based HPV vaccination program in February 2013 [9]. The US also recommends universal vaccination, with the Vaccines for Children (VFC) Program funding HPV vaccination for children aged 9-18 years who are uninsured or underinsured [10]. The UK national school-based programme provides coverage for girls only as is the case in most European countries [11], with the exception of Austria who, in 2014, were the first in Europe to commence a publicly funded universal programme [12]. Switzerland recommend vaccination for boys and men aged $11-26$ [13]. Within country, HPV vaccination for boys is recommended in Saxony (Germany) and Emilia-Romagna/Sicily (Italy). In Canada, of the thirteen provinces and territories, only Prince Edward Island, Alberta and Nova Scotia include boys in their school-based programme [14-17], although the provinces of Manitoba and Quebec may soon follow suit [18-19].

There is substantial debate around the inclusion of males in HPV vaccination programmes [20-21]. Many countries do not include men, and focus on achieving a high coverage in females to promote herd protection, i.e. a reduction in the risk of infection in males due to reduced exposure as a result of female vaccination. There is some emerging evidence that female only vaccination programmes with high female vaccination rates resulted in a one third reduction in the number of boys with genital warts [22]. The incremental benefit of extending the vaccine to males is believed to be dependent on coverage in females. With a low uptake in girls, the benefit of vaccinating boys is easily demonstrated; but when more 
than $70 \%$ of females are vaccinated, the gender neutral vaccine approach appears less effective [23].

However, a female only vaccination strategy leaves a number of men vulnerable to HPV infection, and unvaccinated males are not protected if they move outside of the herd (due to migration or travel) and have sex with an unvaccinated partner. Additionally, this approach will have minimal effect on men-who-have-sex-with-men (MSM). In the UK, the Joint Committee on Vaccination and Immunisation (JCVI), while recognising the merits of universal gender-neutral vaccination, has recently released a recommendation that MSM under age 45 who attend Genito-Urinary Medicine (GUM) or HIV clinics should be offered vaccination [24]. Similarly, British Columbia (Canada) offers HPV vaccination for free to girls and "at-risk" boys (such as boys who are homeless or gay). This approach may have limited efficacy in preventing HPV-related disease, as a significant number of MSM may already have had sexual intercourse before presentation at GUM/HIV clinics [25]. In addition, for the HPV vaccine to be most effective, it should be given at a younger age (9-15 years), before exposure to HPV through sexual contact and when immunogenicity is at its most effective [26]. It is likely that the most effective, practical and ethical solution is to offer HPV vaccination to both adolescent males and females. There is also mounting evidence that universal vaccination is cost effective [27] particularly when the costs associated with oropharyngeal cancer [28] and genital warts treatment [29] are considered. A wider socioeconomic perspective further supports this evidence, with increased benefit to society characterised through improved productivity, increased earnings and enhanced tax revenue due to vaccine related reductions in mortality and morbidity [30].

As countries are increasingly recommending and funding HPV vaccination for males, it is imperative to better understand the knowledge, awareness and attitudes of adolescent boys to HPV and HPV vaccination, in order to ensure uptake is maximised and both boys and girls are protected against HPV-related cancers in the future. The aim of this review was to determine the level of HPV and HPV vaccine knowledge and vaccine acceptance in male adolescents worldwide.

\section{METHODS}

A mixed methods systematic review including both quantitative and qualitative data was conducted.

\section{Search strategy}


In accordance with PRISMA guidelines, relevant literature was identified through an electronic database search of Medline (1966 - December 2015), CINAHL (1982 - December 2015), PsychINFO (1872 - December 2015), PsychARTICLES, Web of Science. Keywords to identify research into HPV knowledge and attitudes were taken from a previous publication focussed on men-who-have-sex-with-men (MSM) [31], and combined with search terms for male adolescents. Keywords used therefore were: (Human Papillomavirus OR HPV) AND (accept* OR aware* OR attitude* OR barrier * OR belie* OR behav* OR benefit* OR comprehend* OR communicat* OR cognit* OR cue OR decision OR educat* OR experience OR intent* OR know* OR motivat* OR norm* OR percep* OR perceive* OR

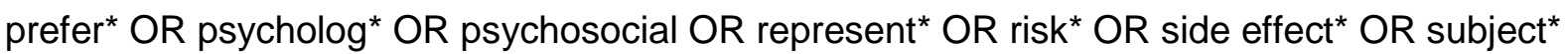
OR understand* OR will*) AND (male OR boy OR son) AND (adolescent* OR child*). The reference list of each relevant study was searched for additional relevant papers.

\section{Eligibility criteria}

Non-interventional studies presented in English that assessed HPV knowledge and provided data on male adolescents i.e. have you heard of HPV? and/or have you heard of HPV vaccine? were included. If available, data on HPV and HPV vaccine perceptions, attitudes and/or HPV vaccine acceptance were also extracted. An adolescent was operationalised in accordance with the WHO definition, which defines adolescence as after childhood, but before adulthood with an age range of $9-19$, although for this review, the upper age limit was extended to 20 years, as many European secondary schools have an upper age limit of 20 years old [32]. Studies solely investigating the prevalence of HPV, studies not specific to HPV vaccination (i.e. general vaccination attitudes), those focused on parent or health care provider opinion on vaccination of adolescent males, and those including an immunosuppressed children or a HIV population were excluded. Reviews, editorials, comments and conference presentations were also excluded.

\section{Study selection}

Following completion of the database searching, and removal of duplicates, titles were divided between 2 reviewers (GP and RM). Studies were selected based on the inclusion/exclusion criteria. Any titles that lead to uncertainty were retained for abstract screening. Abstract and full-text screening was conducted by one reviewer (GP), any ambiguity in terms of study selection and the rationale for inclusion of the final studies were discussed with the review team.

\section{Study quality}


As per Patel et al. [32], to provide an indication of the quality of the included studies, all quantitative papers were assessed using a checklist created using the Centre for EvidenceBased Medicine (CEBM) tool for appraising survey studies and the guidance provided by Pettigrew and Roberts [33]. The Critical Appraisal Skills Programme tool was used to appraise the qualitative studies [34]. These two tools have been used previously in a review of adolescent HPV knowledge in Europe [32]. Two reviewers (RM and GP) completed the checklists for each included study, a third reviewer OS appraised those studies where the quality/fulfilment of criteria could not be agreed between the two main reviewers.

\section{Data synthesis}

Results of this systematic mixed studies review were compiled using a convergent synthesis [35]. A convergent synthesis involves initially synthesising qualitative and quantitative separately, then integrating the qualitative and quantitative summaries.

\section{RESULTS}

As can be seen from Figure 1, 113 studies met the initial inclusion criteria. On full text review, 91 were excluded as they did not focus on HPV specifically $(n=6)$, did not include adolescents ( $n=71)$, had no separate male adolescent data $(n=7)$ or did not assess knowledge of HPV or HPV vaccination ( $n=7$ ). Twenty-two relevant publications were included and are summarised in Table 1. As can be seen from Table 1, three studies consist of the same sample and methodology, but report on different analysis [37,38,41]; consequently 20 studies have resulted in 22 separate publications. All studies were crosssectional, with the majority $(n=17)$ using a self-administered questionnaire to assess HPV knowledge. Two studies used mixed methods [40,52] and one was solely qualitative [43]. Sample sizes ranged from 20 [57] to 2500 [52]. Participants were largely recruited from schools $(n=13)$, but online recruitment $(n=2)$, health centres $(n=1)$, or community sources $(n=4)$, were also used. There was wide representation from across the globe, although most of the included studies were conducted in the US $(n=5)$, Western Europe $(n=7)$ or Australia $(n=2)$. Nevertheless, one study was conducted in Africa [57], one in Hungary [48], one in Romania [42] and three in Asia [52-54].

\section{Study quality}

The methodological quality of the reviewed studies was generally acceptable, with the majority of studies $(n=17)$ being considered to be of moderate to high quality (see Table 2 and 3). The majority of quantitative/mixed method studies studies achieved a satisfactory response rate (59-100\%) ( $n=15)$, with only Samkange-Zeeb [44] not attaining a satisfactory level, although many did not base their sample size on a pre-study consideration of 
statistical power $(n=14)$. The method of recruitment used by a number of studies lead to difficulty in generalising findings, as a large number of the included studies used a convenience sample, and only a few studies recruited in a way whereby the study sample could be considered representative of the population $(n=7)$. All studies were cross-sectional which prevents any statements to be made regarding causality.

\section{HPV knowledge}

All 20 studies either assessed knowledge of HPV or knowledge of HPV vaccination.

Of the 19 quantitative studies, 18 assessed awareness and/or knowledge of HPV (all except [36]), with varying methods of measurement. Eleven studies assessed awareness by asking an initial question 'Have you heard/are you aware of HPV?' [37,38,40-42,44,46-49,50,51,56]; this was followed by combinations of various HPV knowledge questions, largely focussed on what diseases are caused by HPV (different cancers types/genital warts), mode of HPV transmission, who can be affected by HPV, and how to protect against HPV. The remaining 7 studies also assessed knowledge in a variety of ways, from asking a broad question on 'What is HPV'/"What do you know about HPV?" with multiple-choice response options [45,54], or 'Is genital/cervical cancer caused by HPV?" [39,52], or "Have you ever discussed HPV with friends?" [55] Qualitatively, Hilton et al. [43] assessed HPV knowledge via discussions on awareness of disease, and understanding of disease process and symptoms.

Sixteen studies assessed awareness and/or knowledge of HPV vaccination $[36,37,39,40,42,44,46-50,52-56)$. Similar to HPV knowledge, 11 studies assessed awareness initially with a question on 'Have you heard of/are you aware of the HPV vaccine?' $[36,37,39,40,42,44,48,49,50,52,53]$. Moss et al [37] was the sole study to ask directly if respondents were aware that boys could receive the HPV vaccine. In two of these studies, the initial awareness question was followed by various other vaccine knowledge questions such as 'Can you get HPV by getting the vaccine?', 'Will the vaccine protect against other STIs?', 'When should the vaccine be given?' [40,49]. The remaining five studies did not include an initial awareness question, but assessed vaccine knowledge in a variety of ways including indicating yes/no to the statement 'The vaccine won't work if you are sexually active' [54-56], and asking participants to indicate from a list of answers 'What diseases are protected by the vaccine?' [54].

Across continents, regardless of a country's HPV vaccination programme status, boys' knowledge of HPV and/or HPV vaccination was generally low to moderate (5 - 65\% had heard of HPV; 1 - 45\% had heard of HPV vaccination)(Figure 2), and significantly lower than 
female knowledge or awareness where it was compared [36,42,44,47,48,49,56], or at a similar level to the level of knowledge of unvaccinated females $[45,56]$. Low knowledge in boys was also demonstrated in the qualitative study, where boys showed little knowledge of HPV, believing that it only affected female [43]. This is with the exception of three studies where knowledge in both genders was so low that no gender difference was noted $[42,50,57]$. Contrary to this, in two studies male adolescent knowledge was high including a study of adolescent males in Thailand [54] and a recent study of MSM aged 16-20 years in Australia [55]. Interestingly, Songthap et al. [54] found that boys had high knowledge that was comparable to females, but that most boys disagreed that 'HPV infection in men was as important as in women' [54].

Only studies in the US were conducted at a time when vaccination was available in country for adolescent males (since 2009), but despite this, low to moderate knowledge was still recorded (Figure 2) [36,37-41]. For example, a high quality, nationally representative sample survey found that only $25 \%$ of boys aged $11-17$ years old were aware of HPV and $26 \%$ were aware of an HPV vaccine. Of those that were aware of the HPV vaccine, only $38 \%$ were aware that a vaccine was available for boys (approximately $10 \%$ of the overall sample) [37]. However, in a secondary analysis that examined the older $15-17$ year old subsample [41], the percentage of adolescents who reported knowledge of HPV (not HPV vaccination) increased significantly from $25 \%$ to $40 \%(p=0.0003)[41]$ indicating that age may influence HPV knowledge. (The study focussed on sexual disinhibition, so these items were not asked of younger boys). Indeed in other studies with higher male knowledge, the sample included participants over the age of 19 [47,49] which may have elevated the level of the sample's knowledge. This increased knowledge was also reported in another high quality US study that found adolescents over the age of 15 were more likely to report HPV vaccine awareness [36], although this study did not examine HPV knowledge. Contrarily, an older age group did not explain the high level of knowledge recorded in a high quality study of $12-15$ year old Thai students [54]

It is also possible that it may not be age, but sexual activity that influences adolescent knowledge. Sexual orientation seems to impact on level of knowledge, with adolescent MSM having higher knowledge $[40,55]$ although both of these studies are limited by their methodological quality. In Australia, in a study of 200 adolescent (16-20 years) MSM, there was a high level of knowledge, despite male vaccination not being routinely offered at the time of data collection [55]. In a study of urban, low income adolescents in the USA, conducted after the introduction of universal HPV vaccination, a high proportion (77\%) of the $42 \%$ of males who had heard of HPV were MSM, although it should also be noted that the 
mean age of MSM was 18 years old compared to the mean age of the heterosexual adolescents of 16 years [40]. It is possible that those who are identifying as MSM are older and therefore more sexually active (which may increase awareness). In addition, MSM may also have more frequent exposure to STI messages, more health discussions with their physician, and more experience of taking control of their sexual health. This possible association between age and/or sexual activity was also seen in a US study of inner city Caribbean and African American adolescents [39]. This study reported high levels of HPV knowledge in $13-19$ years old; however, this is confounded by half of the sample being 18 or 19 years old, and $70 \%$ reporting sexual activity ( $98.6 \%$ with the opposite sex) [39]. It is important to note that this study was assessed as low quality and that HPV vaccines were administered to boys whose parents reported positive interest in receiving this immunization, which was done during the same clinic visit [39] and this may have impacted on outcome. This also occurred in the Australian MSM study, whereby the participating adolescent males were involved in another HPV infection study that offered free HPV vaccination at the end of the study [55].

As all studies were cross-sectional, it was not possible to determine if time (i.e. allowing HPV vaccination programmes to become more established) impacts level of knowledge.

\section{HPV vaccine attitudes and acceptance}

\section{Association of HPV vaccine acceptance and HPV knowledge}

Thirteen studies examined HPV vaccine acceptance [36-39,40,42,46,48,49,51,52,54,55,57], which was expressed as the percentage of adolescent boys who would be willing to be vaccinated against HPV. In the US (where vaccination was available for adolescent boys) the range for willingness to be vaccination was 30 [38] - 65\% [39], one study reported actual vaccine uptake of $11.5 \%$ [36]. In Europe the range was 40\% [49] - 75\% [51]; Asia 25\% [54] - 30\% [52]; Australia 86\% (MSM sample) [55], in Africa 100\% willingness was reported [57].

There was a general association between level of knowledge and vaccine acceptability, with higher knowledge being associated with greater acceptability [39,40,42,46,49,55], although this data was generated from studies rated low to medium quality. For example, in the UK, boys who were unsure whether to have the vaccine they were significantly less likely to have heard of HPV (44\%) compared with boys who intended $(63 \%)\left(X^{2}(1)=9.35, p=0.002\right)$ or did not intend $(58 \%)$ to receive the HPV vaccine $\left(X^{2}(1)=6.46, p=0.01\right)$ [46]. Similarly, in the US, knowledge was associated with willingness to be vaccinated, with $65 \%$ of the adolescent boys who knew about HPV (i.e. that HPV is associated with genital cancer) being significantly associated with interest in receiving HPV vaccination [39]. However, as 
previously stated, this was rated a low quality study, as vaccination was offered at end of study and this may have recruited participants more accepting of vaccination.

Notably, some studies (of medium to high quality) did not find a positive association between HPV knowledge and willingness to be vaccinated. For example, in a high quality US study conducted on a representative sample of adolescent boys from a rural location, $40 \% \mathrm{knew}$ about HPV vaccination, but only $1.4 \%$ had received the full three doses of vaccine [36]. It should be noted that the adolescents in this study were not asked specifically if they knew the vaccine was available for boys, so they might have been only aware of female vaccination. This was also demonstrated in another high quality US study conducted on a nationally representative sample, where only $10 \%$ of male adolescents were aware of the existence of an HPV vaccine for boys specifically, while $26 \%$ were aware of the HPV vaccine in general [37]. This study also does not support the hypothesis that acceptance and knowledge are positively correlated, as despite low knowledge of HPV (10\% of sample), almost $30 \%$ were willing to be vaccinated [37]. Similarly, in another high quality study conducted in Hungary, despite low knowledge in both primary and secondary school boys (20\% and $29 \%$ respectively knew what HPV was), $60 \%$ of boys would request the vaccine if it was free [48]. Likewise in Mali, in a small study conducted prior to the introduction of an HPV vaccination programme, $100 \%$ of a convenience sample of adolescents $(n=20)$ aged $12-17$ years, said they would be willing to be vaccinated, despite very low knowledge in both males and females [57]. A similar pattern was seen in another high quality study in Sweden [51] where despite low knowledge, $74 \%$ of $15-16$ year old boys indicated they would like to be vaccinated.

\section{Attitudes and HPV vaccine acceptance}

The majority of studies also examined factors associated with acceptance [37-41,43,48$52,54,55,57]$. Reasons for non-acceptance of vaccination were based around current sexual inactivity [42,46,51], regular condom use [39], or regular physical health examinations [39] and so the perceived risk of acquiring HPV was low. Those boys who had a high perceived likelihood of becoming infected [37], either from having a high number of sexual partners [39], previous STIs [39], or partaking in risky sexual behaviour [40] had a higher acceptance of vaccination. In addition, in a Swedish study, knowledge that the vaccine also protected against genital warts increased acceptance [51], which may indicate that the participants were more concerned or perceived themselves at greater risk of contracting genital warts.

Other reasons for vaccine acceptance were focused on severity, i.e. the perception that contracting HPV would have serious implications (largely around the fear of disease and risk 
of developing cancer) $[40,46,50,52]$, or regret if they later became infected with HPV [37], and wanting to protect future partners [37]. As noted earlier, it is important to differentiate between willingness to be vaccinated and actual receipt of vaccination, for example, and intention to receive the vaccine. In Sweden, $74 \%$ of boys aged $15-20$ years indicated they would like to be vaccinated, but crucially only $4 \%$ had the intention of getting vaccinated in the future [50].

In addition to perceived low risk, other reasons boys expressed for not wanting to receive an HPV vaccine were regarding cost (price was too high) [48,55,57], and generic vaccination concerns such as worries about side effects [37,40,48,52], vaccine safety [54], fear of needles $[43,48]$, or pain $[37,42,43]$. In India, low vaccine acceptance was also linked to recent media coverage of vaccine-related deaths [52].

\section{DISCUSSION}

In recent years, there has been an increase in studies examining knowledge and awareness of HPV in adolescent boys. This is likely reflective of changes in policies in an increasing number of countries worldwide to recommend a gender-neutral vaccine strategy. The majority of studies have been cross-sectional and conducted in the US and Europe; however, a small number of Asian and African countries have also examined the issue. This reflects a fundamental gap in knowledge and research on HPV and its implications given that low middle income countries (LMICs) report much higher prevalence of HPV (e.g. 33\% in sub-Saharan Africa) [58], with all viral infections (including infection with HPV) leading to one fifth of cancer deaths in LMICs [59]. In addition, LMICs bear most of the burden of the global HIV epidemic [60]. The higher level of co-infection with HPV in those positive for HIV in the African population for example, increases associated cancer risk.

As can be noted from this systematic review, comparison and synthesis of research concerning HPV knowledge and attitudes is made more difficult to interpret as there is currently no universal definition of vaccine acceptance, and no universally accepted tool for its measurement or for the measurement of HPV knowledge. The included studies assessed knowledge differently, posing different questions to participants, for example, 'Have you ever heard of HPV?' or 'Which virus causes cervical cancer?'. However, regardless of question asked, it is important to note that adolescent male knowledge was statistically lower than their female counterparts. There appears to be a tiered level of knowledge and it is important to be able to distinguish between being aware of HPV; being aware that there are HPV vaccines; and knowing the vaccines are available for boys, which was highlighted in the nationally represented study of US adolescents [37]. This inconsistency between studies 
makes comparison problematic, as the outcome of interest is measured in various ways, making it difficult to draw conclusions and recommendations and to develop methods to enhance vaccine acceptance.

In general, adolescent boys' knowledge of HPV was below that of female adolescents though there were exceptions to this, with two studies suggesting that female and male adolescent knowledge was so low no gender difference was detected [50,57], and a study of male adolescents in Thailand whose knowledge was as high as that of the female adolescents [54]. It was difficult in certain studies to separate the adolescent outcome from the young adult $[39,44,47,49,52,55]$ and it is possible that the age of the sample and sexual experience could be contributing to the variability in knowledge reported. There is an indication that knowledge may increase with increasing age and sexual experience. We know that the HPV vaccine is most effective if given before commencement of sexual activity and hence possible exposure to HPV [61], therefore efforts to enhance knowledge and awareness need to be concentrated on younger adolescents.

Insufficient knowledge of HPV in adolescent boys may be reflective of many countries' information campaigns being targeted to females only, with a clear focus on cervical cancer. This connotation that HPV is a women's problem, and its subsequent impact on primary prevention efforts is referred to as the 'feminisation of HPV' [62]. This 'feminisation' is important as it impacts on how the general public, health care professionals and policy makers view HPV and HPV vaccination as a female only issue [62]. It is also possible that low male knowledge (compared to females) is due to males not being recommended or offered the HPV vaccine at time of data collection. This was not the case in the US; despite the vaccine being available for males at time of data collection; knowledge in adolescent males was still low. This could be reflective of how the vaccine is offered in the US via a health care practitioner and not offered through school-based programmes. This approach is leading to low vaccine uptake in the US, there is evidence to suggest that vaccine uptake in adolescent males is low; in 2012 only $20.8 \%$ of US boys aged $13-17$ received at least one dose, and only $6.8 \%$ receiving the full three dose schedule [63]. This can be contrasted with a school-based universal vaccination programme in the Canadian province of Prince Edward Island, where $79 \%$ of adolescent boys received all three doses of vaccination (although again male vaccination was significantly lower than females $(85 \% ; p=0.004)$ ) [64]. Based on the prevailing evidence, what is needed is better health education and public information to maximise public awareness that HPV affects both men and women and should be of concern of both sexes. As illustrated by Hoglund et al. [50], it is possible that HPV vaccine marketing has only reached health care professionals and not the general 
public and this may be why adolescent HPV knowledge is so low. Nevertheless, it is crucial that when HPV is marketed to the general public it is not presented as a vaccine for females, but as a universal vaccine for all [62].

Although knowledge is low, it is important to note that knowledge was not always predictive of vaccine acceptance and uptake. In this review, the high quality studies indicated that knowledge was not predictive of willingness to be vaccinated or actual vaccine uptake. Parental and health care provider knowledge, acceptance and recommendation, though not specifically examined in this review, was seen as an important correlate of vaccine acceptance in adolescents $[36,40,43]$. There is an opportunity for education to extend beyond vaccination to HPV transmission and other prevention measures. As knowledge and acceptance are not always correlated, i.e. an adolescent may consider vaccination without adequate knowledge, health care professionals responsible for vaccination should use the opportunity to inform adolescents about HPV and its associated cancers. In research studies, we should not look at knowledge in isolation as it is not always predictive of uptake; in research of this nature; attitudes to vaccination may be more informative. Although there may be a discrepancy between vaccine intent and actual receipt of vaccination. The crosssectional nature of the research included in this review makes it difficult to determine if vaccine acceptance or intent to vaccinate leads to actual vaccine uptake.

Few studies on vaccine acceptance in adolescent boys are guided by a theoretical framework around decision making or behaviour change, which makes the identification and exploration of factors that influence vaccine uptake difficult. In future research, a theoretical framework such as the Precaution Adoption Process Model (PAPM), a model of behaviour change with six stages of decision-making [65], may be beneficial for work of this nature. The PAPM categorises individuals as 1) unaware 2) unengaged, 3) undecided 4) decided not to act 5) decided to act 6) acting. This model applied in a longitudinal survey would allow for the crucial identification of factors that caused the change in health behaviour. The PAPM is suited to research in vaccine acceptance and uptake, as it identifies those who are aware of the vaccine but decided not to act. The categorisation of individuals who have decided to act and those individuals who have acted (i.e. received the vaccine) allows the crucial identification of factors that lead individuals to receive the vaccine. It is likely that a different intervention would be needed for individuals at different stages of the PAPM. For example, someone is stage 1 (unaware) may benefit most from awareness raising interventions in the media or from health care professionals; whereas someone who has decided to act may need assistance in accessing the vaccine. 


\section{Future research recommendations}

It is imperative that future research utilises consistent measures of HPV knowledge and attitudes to facilitate interpretation and comparison across studies internationally. One scale that could be used is that developed by Waller et al [66], which has demonstrated satisfactory psychometric properties and could be appropriately adapted for use to various other populations, for example, adolescents. Prospective longitudinal studies designed and informed by the PAPM as described above, would be more informative providing data on factors that influenced the move from vaccine intention to uptake. In addition, more complex research designs to determine whether age or sexual activity impact on HPV and HPV vaccine knowledge would be beneficial.

From a policy perspective, it is important to identify ways in which awareness among male adolescents can be increased, while also using an evidence based approach to support recommendations regarding universal HPV vaccination. More in depth analysis of the reasons for high awareness among male adolescents in countries such as Thailand may provide valuable insights that can have broader application. Data from countries/regions where HPV vaccination in males has been implemented can help inform policy decision making, and this data should include heath economic analysis concerning the cost effectiveness of a universal vaccination approach. Public awareness campaigns such as HPV Action's "Jabs for the Boys" in the UK can also be effective, particularly if they are linked with effective lobbying of decision makers by coalitions of healthcare professionals and patient advocates 


\section{FUNDING}

This research did not receive any specific grant from funding agencies in the public, commercial, or not-for-profit sectors.

\section{References}

1. Forman D., de Martel C., Lacey C.J., Global burden of human papillomavirus and related diseases, Vacc. 30 (2012) F12 - 23.

2. de Sanjose S., Quint W., Alemany L., Geraets D., Klaustermeier J., Lloveras, B., Human papillomavirus genotype attribution in invasive cervical cancer: a retrospective cross-sectional worldwide study, Lanc Onc. 11 (2010) 1048-1056.

3. Parkin D., Bray F., Chapter 2: The burden of HPV-related cancers, Vacc. 24 (2006) S11-S25.

4. Kensler T., Spira A., Garber J., Szabo E., Lee J., Dong Z., Transforming Cancer Prevention through Precision Medicine and Immune-oncology, Canc Prev Res. 9 (2016) 2-10.

5. Gillison M., Chaturvedi A., Lowy D, HPV prophylactic vaccines and the potential prevention of noncervical cancers in both men and women, Cancer. 113 (2008) 3036-3046.

6. de Martel C., Ferlay J., Franceschi S., Vignat J., Bray F., Forman D., \& Plummer M, Global burden of cancers attributable to infections in 2008: a review and synthetic analysis, Lanc Onc. 13 (2012) 607-615.

7. Chaturvedi A., Engels E., Pfeiffer R., Hernandez B., Xiao W., Kim E., Human Papillomavirus and Rising Oropharyngeal Cancer Incidence in the United States, J Clin Onc. 29 (2011) 4294-4301.

8. Lacey C., Lowndes C., Shah K., Chapter 4: Burden and management of noncancerous HPV-related conditions: HPV-6/11 disease, Vacc. 24 (2006) S35-S41.

9. Australia Government Department of Health. Human papillomavirus. Immunise Australia Program (2014).

10. Centers for Disease Control and Prevention. VFC Program. Available from http://www.cdc.gov/features/vfcprogram/ [last accessed 28 Jun 2016].

11. European centre for disease prevention and control (ECDC) Vaccine schedule. Recommended immunisations for human papillomavirus infection. http://vaccineschedule.ecdc.europa.eu/Pages/Scheduler.aspx [accessed 27 Apr 2016].

12. Smith M.A., Canfell K., Incremental benefits of male HPV vaccination: accounting for inequality in population uptake, PLoS ONE. 9(2014) e101048.

13. Switzerland's Federal Public Health Office maladies transmissibles Vaccination contre les HPV : recommandation de vaccination complémentaire pour les 
garçons et jeunes hommes âgés de 11 à 26 ans. bulletin 102 mar 2015141 150 Office fédéral de la santé publique (OFSP).

14. Recommendations for human papillomavirus immunization programs. Ottawa: Canadian Immunization Committee, Public Analysis CMAJ 5 Health Agency of Canada; 2014. Available:

http://publications.gc.ca/collections/collection_2014/aspc-phac/HP40-107-2014eng.pdf (accessed 2016 Apr. 12).

15. Bonanni P., Bechini A., Donato R., et al. Human papilloma virus vaccination: impact and recommendations across the world, Ther Adv Vaccines. 3 (2015) 312.

16. Colbert Y. HPV vaccine for Nova Scotia boys called 'groundbreaking.' CBC News 2015 Apr. 13. Available: www.cbc.ca/news /canada/nova-scotia/hpv-vaccine-fornova-scotia-boys-called-groundbreaking-1.3031169 (accessed 2016 Apr. 7).

17. Grant K. Nova Scotia to include boys in HPV vaccination schedule. Globe and Mail [Toronto] 2015 Apr. 10. Available: www.theglobe andmail.com/life/healthand-fitness/health/nova-scotia-to-include -boys-in-hpv-vaccinationschedule/article23886885 (accessed 2016 Feb. 2).

18. Manitoba's immunization program: vaccines offered free-of charge (eligibility criteria for publicly-funded vaccines). Winnipeg: Communicable Disease Control. Manitoba Health, Healthy Living and Seniors. 2015. Available:

www.gov.mb.ca/health/public health/cdc/vaccineeligibility.html (accessed 2016 Apr. 12).

19. Human papillomavirus (HPV) vaccine. Quebec: Gouvernement du Québec; 2016. Available: http://sante.gouv.qc.ca/en/conseils -et -prevention/vaccin-contre-lesinfections-par-les-virus-du -papillome -humain-vph (accessed 2016 Apr. 12).

20. Stanley M., Vaccinate boys too, Nature. 488 (2012) S10.

21. Shapiro G.K., Perez S., Rosberger Z., Including males in Canadian human papillomavirus vaccination programs: a policy analysis, Canadian Medical Association Journal. (2015) 1-5.

22. Drolet M., Benard E., Boily M-C., Ali H., Baandrup L., Bauer H., Beddows S., Brisson J., Brotherton J.M., Cummings T., Donovan B., Fairley C.K., Flagg E.W., Johnson A.M., Kahn J.A., Kavanagh K., Kjaer S.K., Kliewer E.V., LemieuxMellouki P., Markowitz L., Mboup A., Mesher D., Niccolai L., Oliphant J., Pollock K.G., Soldan K., Sonnenberg P., Tabrizi S.N., Tanton C., Brisson M., Population level impact and herd effects following human papillomavirus vaccination programmes: a systematic review and meta-analysis, The Lancet Infectious Diseases. 15 (2015) 565-580.

23. Marty R., Roze S., Bresse X., Largeron N., Smith-Palmer J., Estimating the clinical benefits of vaccinating boys and girls against HPV-related diseases in Europe, BMC Cancer. 13(2013) 10. 
24. Department of Health and Public Health England. JCVI statement on HPV vaccination of men who have sex with men. 2015. Available from:

https://www.gov.uk/government/publications/jcvi-statement-on-hpv-vaccinationof-men-who-have-sex-with-men [Last accessed 7th Feb 2016].

25. Zou H., Tabrizi S., Grulich A., Garland S., Hocking J., Bradshaw C., Morrow A., Prestage G., Cornall A.M., Fairley C.K., Chen M.Y., Early acquisition of anogenital human papillomavirus among teenage men who have sex with men. The Journal of Infectious Diseases. 209 (2014) 642-651.

26. Food and Drug Administration. Highlights of prescribing information. Gardasil (human papillomavirus quadrivalent [types 6, 11, 16 and 18]). Silver Spring, MD: Food and Drug Administration; 2011. Available at http://www.fda.gov/downloads/biologicsbloodvaccines/vaccines/approvedproduct s/ucm111263.pdf

27. Bogaards J.A., Wallinga J., Brakenhoff R.H., Meijer C.J.L.M., Berkhof J., Direct benefit of vaccinating boys along with girls against oncogenic human papillomavirus: Bayesian evidence synthesis, BMJ. 350 (2015) h2016.

28. Graham D., Isaranuwatchai W., Habbous S., de Oliveira C., Liu G., Siu L., Hoch J., A cost-effectiveness analysis of human papillomavirus vaccination of boys for the prevention of oropharyngeal cancer, Cancer. 121 (2015) 1785-1792.

29. Bresse X., Goergen C., Prager B., Joura E., Universal vaccination with the quadrivalent HPV vaccine in Austria: impact on virus circulation, public health and cost-effectiveness analysis, Expert Review of Pharmacoeconomics \& Outcomes Research, 14 (2014) 269-281.

30. Kotsopoulos N., Connolly M., Remy V., Quantifying the broader economic consequences of quadrivalent human papillomavirus (HPV) vaccination in Germany applying a government perspective framework, Health Economics Review. 5 (2015) 23.

31. Nadarzynski T., Smith H., Richardson D., Jones C., Llewellyn C., Human papillomavirus and vaccine-related perceptions among men who have sex with men: a systematic review, Sex Transm Infect. 90 (2014) 515-523.

32. Patel H., Jeve Y.B., Sherman S.M., Moss E.L., Knowledge of human papillomavirus and the human papillomavirus vaccine in European adolescents: a systematic review. Sex Transm Infect (2016) 1-6.

33. Pettigrew M., Roberts $\mathrm{H}$., Systematic reviews in the social sciences: a practical guide. Oxford: Blackwell (2006).

34. CASP. Critical appraisal skills programme-10 questions to help you make sense of qualitative research. Available from http://media.wix.com/ugd/dded87 29c5b002d99342f788c6ac670e49f274.pdf [last accessed 26 June 2016] 
35. Pluye P., Hong Q.N., Combining the power of stories and the power of numbers: mixed methods research and mixed studies reviews, Annu Rev Public Health. 35 (2014) $29-45$.

36. Bhatta M.P., Phillips L., Human Papillomavirus vaccine awareness, uptake and parental and health care provider communication among 11- to 18-year-old adolescents in rural Appalachian Ohio County in the United States, The Journal of Rural Health. 31 (2015) 67-75.

37. Moss J.L., Reiter P.L., Brewer N.T., HPV vaccine for teen boys: dyadic analysis of parents' and sons' beliefs and willingness, Prev Med. 78 (2015) 65-71.

38. Reiter P.L., McRee A.L., Kadis J.A., Brewer N.T., HPV vaccine and adolescent males, Vaccine. 29 (2011) 5595-5602.

39. Shao S.J., Nurse C., Michel L., Joseph M.A., Attitudes and perceptions of the human papillomavirus vaccine in Caribbean and African American adolescent boys and their parents, J Pediatr Adolesc Gynecol. 28 (2015) 373-377.

40. Gutierrez B., Leung A., Jones K.T., Smith P., Silverman R., Frank I., Leader A.E., Acceptability of the human papillomavirus vaccine among urban male adolescent males, Am J Men's Health. 7 (2013) 27-36.

41. Mayer M.K., Reiter P., Zucker R., Brewer N.T., Parents' and sons' beliefs in sexual disinhibition after human papillomavirus vaccination, Sex Transm Dis. 40 (2013) 822-828.

42. Maier C., Maier T., Neagu C.E., Vladareanu R., Romanian adolescents' knowledge and attitudes towards human papillomavirus infection and prophylactic vaccination, Eur J Obstet Gynecol Reprod Biol. 195 (2015) 77-82.

43. Hilton S., Patterson C., Smith E., Bedford H., Hunt K., Teenagers' understandings of and attitudes towards vaccines and vaccine-preventable diseases: a qualitative study, Vacc. 31 (2013) 2543-2550.

44. Samkange-Zeeb F.N., Mikolajczyk R.T., Zeeb H., Awareness and knowledge of sexually transmitted diseases among secondary school students in two German cities, J Community Health. 38 (2013) 293-300.

45. Stocker P., Dehnert M., Schuster M., Wichmann O., Delere Y., Human papillomavirus vaccine uptake, knowledge and attitude among $10^{\text {th }}$ grade students in Berlin, Germany, 2010, Human Vaccines \& Immunotherapeutics. 9 (2013) $74-82$.

46. Forster A.S., Marlow L.A., Wardle J., Stephenson J., Waller J., Interest in having HPV vaccination among adolescent boys in England, Vacc. 30 (2012) 45054510.

47. Sopracordevole F., Cigolot F., Gardonio V., Di Giuseppe J., Boselli F., Ciavattini A., Teenagers' knowledge about HPV infection and HPV vaccination in the first 
year of the public vaccination programme, Eur J Clin Microbiol Infect Dis. 31 (2012) $2319-2325$.

48. Marek E., Dergez T., Rebek-Nagy G., Kricskovics A., Kovacs K., Bozsa S., Kiss I., Ember I., Gocze P., Adolescents' awareness of HPV infections and attitudes towards HPV vaccination 3 years following the introduction of the HPV vaccine in Hungary, Vacc. 29 (2011) 8591-8598.

49. Pelucchi C., Esposito S., Galeone C., Semino M., Sabatini C., Picciolli I., Consolo S., Milani G., Principi N., Knowledge of human papillomavirus infection and its prevention among adolescents and parents in the Greater Milan area, Northern Italy, BMC Public Health. 10 (2010) 378.

50. Hoglund A.T., Tyden T., Hannerfos A.K., Larsson M., Knowledge of human papillomavirus and attitudes to vaccination among Swedish high school students, International Journal of STD \& AIDS. 20 (2009) 102-107.

51. Gottvall M., Larsson M., Hoglund A.T., Tyden T., High HPV vaccine acceptance despite low awareness among Swedish upper secondary school students, Eur J Contracept Reprod Health Care. 14 (2009) 399-405.

52. Hussain S., Nasare V., Kumari M., Sharma S., Khan M.A., Das B.C., Bharadwaj M., Perception of human papillomavirus infection, cervical cancer and HPV vaccination in North Indian population, PLOS One. 9 (2014) e112861.

53. Tang S.Y., Liu Z.H., Li L., Cai H.L., Wan Y.P., Awareness and knowledge about human papillomavirus among high school students in China, J Reprod Med. 59 (2014) 44-50.

54. Songthap A., Pitisuttithum P., Kaewkungwal J., Fungladda W., Bussaratid V., Knowledge attitudes, and acceptability of a human papilloma virus vaccine among students, parents and teachers in Thailand, Southeast Asian J Trop Med Public Health. 43 (2012) 340-353.

55. Zou H., Grulich A.E., Cornall A.M., Tabrizi S.N., Garland S., Prestage G., Bradshaw C., Hocking J.S., Morrow A., Fairley C.K., Chen M.Y., How very young men who have sex with men view vaccination against human papillomavirus, Vacc. 32 (2014) 3936-3941.

56. Agius P.A., Pitts M.K., Smith A.M.A., Mitchell A., Human papillomavirus and cervical cancer: Gardasil® vaccination status and knowledge amongst a nationally representative sample of Australian secondary school students, Vacc. 28 (2010) 4416-4422.

57. Poole D.N., Tracy J.K., Levitz L., Rochas M., Sangare K., Yekta S., Tounkara K., Aboubacar B., Koita O., Lurie M., De Groot A.S., A cross-sectional study to assess HPV knowledge and HPV vaccine acceptability in Mali, PLOS One. 8 (2013) e56402.

58. de Souza, J., Hunt, B., Asirwa, F., Adebamowo, C., \& Lopes, G. (2015). Global Health Equity: Cancer Care Outcome Disparities in High-, Middle-, and Low- 
Income Countries. Journal Of Clinical Oncology, 34(1), 6-13.

http://dx.doi.org/10.1200/jco.2015.62.2860

59. de Martel, C., Ferlay, J., Franceschi, S., Vignat, J., Bray, F., Forman, D., \& Plummer, M. (2012). Global burden of cancers attributable to infections in 2008: a review and synthetic analysis. The Lancet Oncology, 13(6), 607-615. http://dx.doi.org/10.1016/s1470-2045(12)70137-7

60. Shao, Y., \& Williamson, C. (2011). The HIV-1 Epidemic: Low- to Middle-Income Countries. Cold Spring Harbor Perspectives in Medicine, 2(3), a007187-a007187. http://dx.doi.org/10.1101/cshperspect.a007187

61. National Cancer Institute. Accelerating HPV Vaccine Uptake: Urgency for Action to Prevent Cancer. A Report to the President of the United States from the President's Cancer Panel. Bethesda, MD: National Cancer Institute; 2014. http://deainfo.nci.nih.gov/advisory/pcp/annualReports/HPV/index.htm

62. Daley E.M., Vamos C.A., Zimet G.D., Rosberger Z., Thompson E.L., Merrell L., The feminization of HPV: reversing gender biases in US human papillomavirus vaccine policy, AJPH. 106 (2016) e1-e2.

63. National Cancer Institute, Accelerating HPV Vaccine Uptake: Urgency for Action to Prevent Cancer. A Report to the President of the United States from the President's Cancer Panel. Bethesda, MD: National Cancer Institute, (2014).

64. McClure C.A., MacSwaub M-A., Morrison H., Sanford C.J., Human papillomavirus vaccine uptake in boys and girls in a school-based vaccine delivery program in Prince Edward Island, Canada, Vacc. 33 (2015) 1786-1790.

65. Weinstein N., The precaution adoption process, Health Psychology. 7 (1988) 355-386.

66. Waller J., Ostini R., Marlow L., McCafferty K., Zimet G., Validation of a measure of knowledge about human papillomavirus (HPV) using item response theory and classical test theory, Prev Med. 56 (2013) $35-40$. 
Figure 1 PRISMA flow diagram

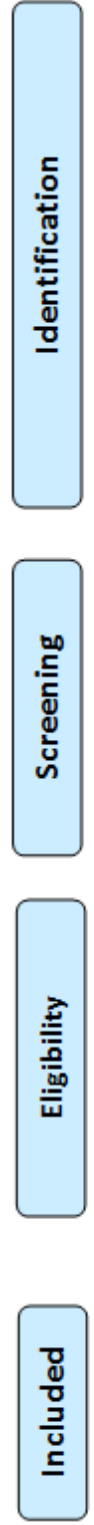

Records identified through

database searching (CINAHL,

Medline, PsycINFO, PsycARTICLES, and Web of Science).

$(n=3845)$

Additional records identified through other sources $(n=5)$

Records after duplicates removed $(n=3348)$

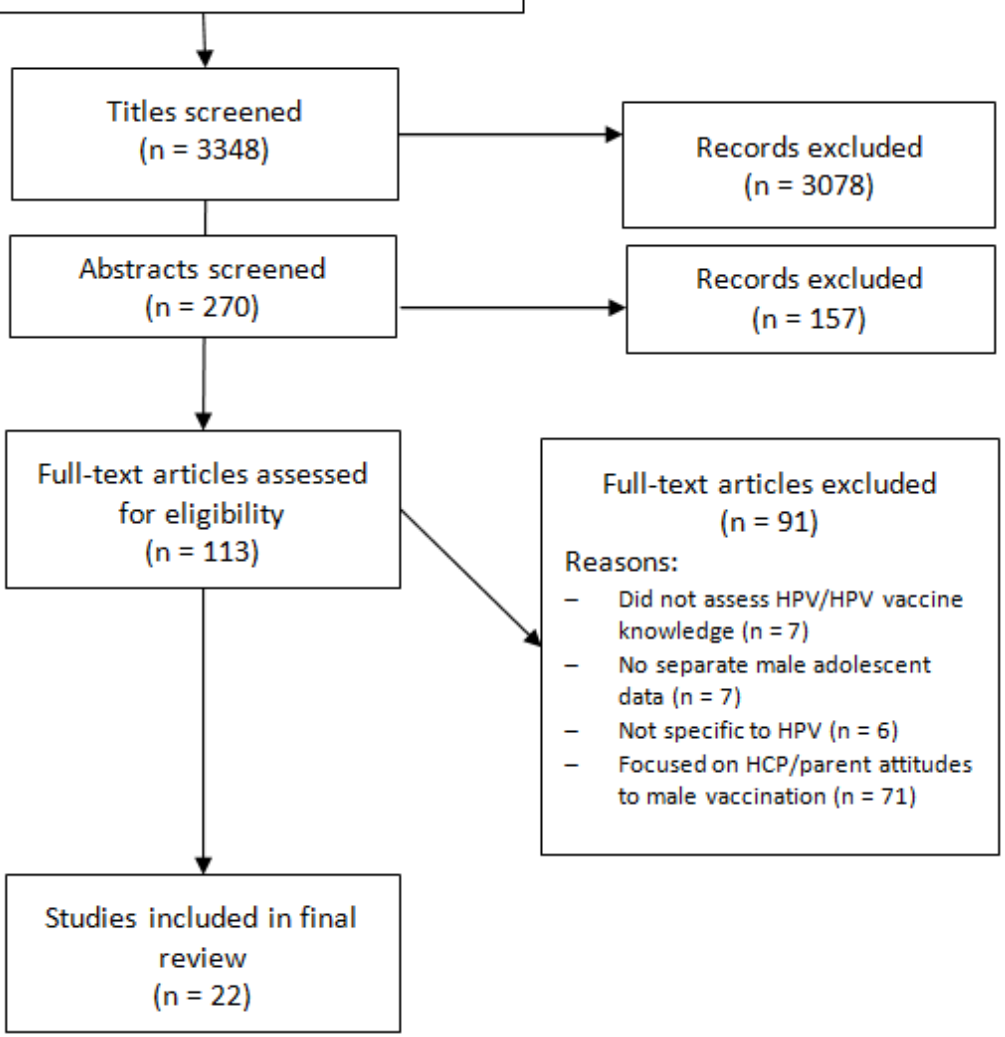


Figure 2 HPV and HPV vaccine knowledge grouped per Continent

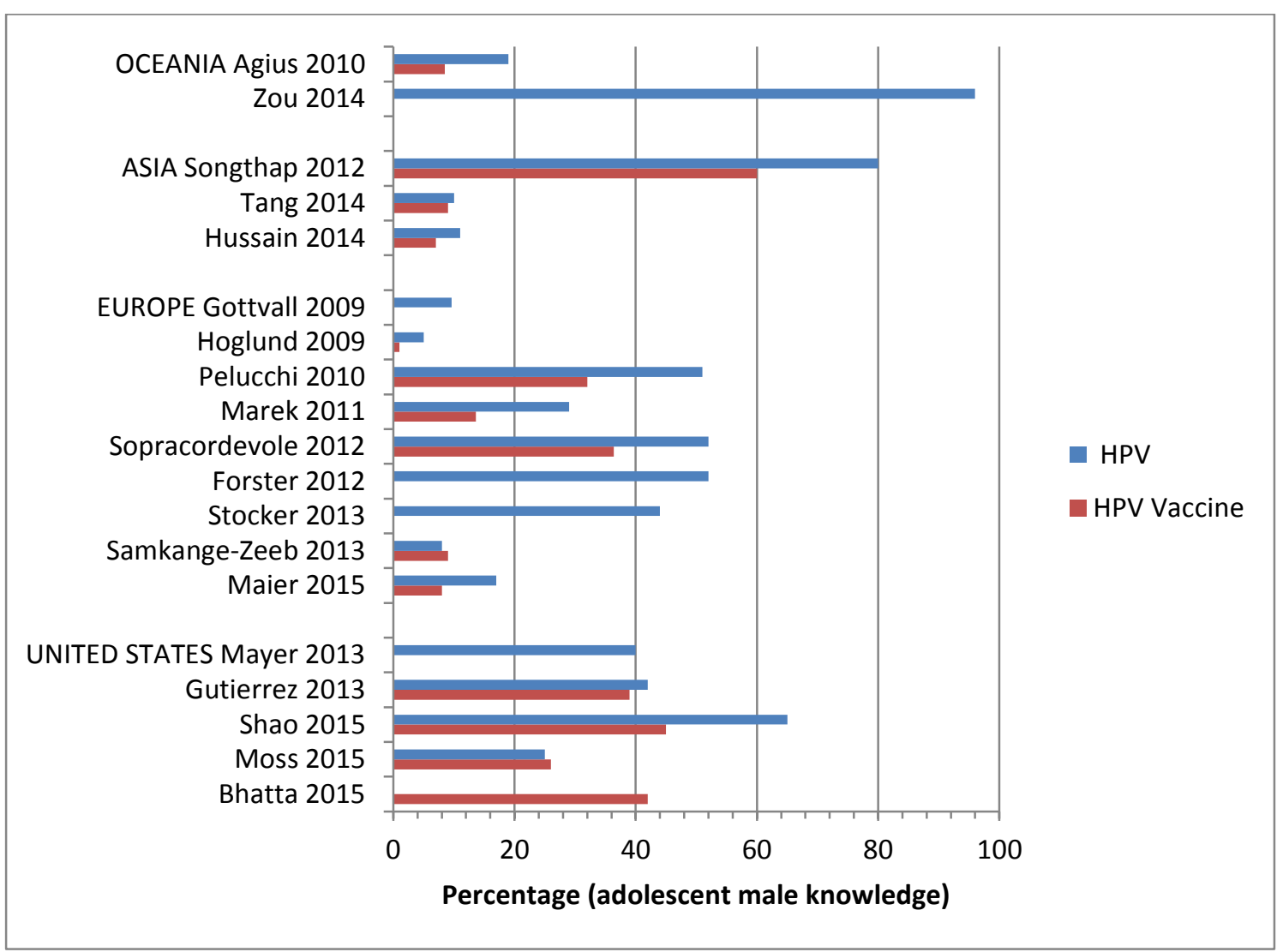


Table 1: Included studies table

\begin{tabular}{|c|c|c|c|c|c|c|c|c|c|}
\hline Study & Design & $\begin{array}{l}\text { Country } \\
\text { and } \\
\text { vaccine } \\
\text { status** }\end{array}$ & Sample & $\begin{array}{l}\text { HPV } \\
\text { vaccine } \\
\text { status }\end{array}$ & Setting & $\begin{array}{l}\text { HPV knowledge/HPV } \\
\text { vaccine knowledge }\end{array}$ & $\begin{array}{l}\text { HPV acceptance (\% boys } \\
\text { vaccinated/willing to be } \\
\text { vaccinated) }\end{array}$ & $\begin{array}{l}\text { Factors associated with } \\
\text { acceptance. }\end{array}$ & $\begin{array}{l}\text { Study } \\
\text { quality }\end{array}$ \\
\hline \multicolumn{10}{|l|}{ Americas } \\
\hline $\begin{array}{l}\text { Bhatta } \\
2015[36]\end{array}$ & $\begin{array}{l}\text { C/S } \\
\text { YRBSS }\end{array}$ & $\begin{array}{l}\text { USA; boys } \\
\text { aged 9-26 }\end{array}$ & $\begin{array}{l}\text { 1299 (674 } \\
\text { boys, } 625 \\
\text { girls) } \\
11-18 \text { years } \\
\text { Rural } \\
\text { Appalachian } \\
\text { Ohio } \\
\text { RR 69-82\% }\end{array}$ & $\begin{array}{l}11.5 \% \\
\text { boys } \\
\text { have } \\
\text { received } \\
1 \text { dose } \\
\text { hpv } \\
\text { vaccine }\end{array}$ & School & $\begin{array}{l}\text { Assessed knowledge of HPV } \\
\text { vaccine only. } \\
42.1 \% \text { boys knew about } \\
\text { HPV vaccine. }\end{array}$ & $\begin{array}{l}11.5 \% \text { boys have received } 1 \\
\text { dose of HPV vaccine. } 1.4 \% \\
\text { received all } 3 \text { doses. }\end{array}$ & Not examined & $\mathrm{H}$ \\
\hline $\begin{array}{l}* * \text { Moss } \\
2015[37] \\
\text { And } \\
\text { Reiter } \\
2011[38]\end{array}$ & $\begin{array}{l}\text { C/S } \\
\text { Online } \\
\text { SAQ }\end{array}$ & USA; & $\begin{array}{l}412 \text { boys } \\
11-17 \text { years } \\
\text { National } \\
\text { sample; } 2010 \\
\text { HIS study } \\
\text { RR } 73 \%\end{array}$ & NK & Online & $\begin{array}{l}\text { Assessed knowledge of HPV } \\
\text { and knowledge of HPV } \\
\text { vaccine. } \\
25 \% \text { aware of HPV, } 26 \% \\
\text { aware of vaccine, of these } \\
38 \% \text { aware that boys can } \\
\text { receive vaccine. }\end{array}$ & $\begin{array}{l}28.9 \% \text { were willing to be } \\
\text { vaccinated. }\end{array}$ & $\begin{array}{l}3.57 \text { believed it was } \\
\text { important to protect health } \\
\text { (on } 5 \text { point scale). Perceived } \\
\text { likelihood of getting HPV was } \\
2.02 \text { (on } 4 \text { point scale). } \\
\text { Anticipated regret of HPV } \\
\text { infection was } 3.14 \text { (on } 4 \text { point } \\
\text { scale). }\end{array}$ & $\mathrm{H}$ \\
\hline $\begin{array}{l}\text { Shao } \\
2015 \text { [39] }\end{array}$ & $\begin{array}{l}\text { C/S } \\
\text { SAQ } \\
2011- \\
2012\end{array}$ & $\begin{array}{l}\text { USA; boys } \\
9-26\end{array}$ & $\begin{array}{l}101 \\
\text { Caribbean } \\
\text { and AA boys } \\
\text { range } 13-19 ; \\
53(13-17) ; 48 \\
(18+) . \\
\text { RR } 79 \%\end{array}$ & NK & $\begin{array}{l}\text { Medical } \\
\text { clinic }\end{array}$ & $\begin{array}{l}\text { Assessed knowledge of HPV } \\
\text { and knowledge of HPV } \\
\text { vaccine. } \\
65 \% \text { knew what HPV was; } \\
27 \% \text { knew HPV caused } \\
\text { cervical cancer and rectal } \\
\text { cancer in males. } 45 \% \text { heard } \\
\text { of the vaccine. }\end{array}$ & $\begin{array}{l}65 \% \text { interested in receiving } \\
\text { the vaccine } \\
\text { Higher knowledge associated } \\
\text { with greater acceptability. }\end{array}$ & $\begin{array}{l}\text { Condom use reduced interest } \\
\text { in HPV vaccine; increase no of } \\
\text { sexual partners increased } \\
\text { interest in vaccine. Routine } \\
\text { physical exam less likely to } \\
\text { have an interest in vaccine; } \\
\text { previous STI increased } \\
\text { interest. }\end{array}$ & $L$ \\
\hline
\end{tabular}




\begin{tabular}{|c|c|c|c|c|c|c|c|c|c|}
\hline $\begin{array}{l}\text { Gutierrez } \\
2013[40]\end{array}$ & $\begin{array}{l}\mathrm{C} / \mathrm{S} \\
\mathrm{SAQ} \text { and } \\
\mathrm{FG}\end{array}$ & $\begin{array}{l}\text { USA; boys } \\
\text { aged } 9-26\end{array}$ & $\begin{array}{l}76 \text { boys } \\
13-21 \text { years } \\
\text { Urban; Low } \\
\text { income; } \\
\text { Philadelphia } \\
\text { RR? }\end{array}$ & UV & Comm & $\begin{array}{l}\text { Assessed knowledge of HPV } \\
\text { and knowledge of HPV } \\
\text { vaccine. } \\
42 \% \text { heard of HPV ( } 77 \% \\
\text { MSM), } 39 \% \text { heard of } \\
\text { vaccine } \\
\text { [18\% heterosexual heard of } \\
\text { HPV; } 77 \% \text { MSM] }\end{array}$ & $\begin{array}{l}50 \% \text { said they would get } \\
\text { vaccinated within the next } 12 \\
\text { months. } \\
\text { Higher knowledge associated } \\
\text { with greater acceptability. }\end{array}$ & $\begin{array}{l}60 \% \text { boys believe vaccination } \\
\text { would be easy. } 68 \% \text { believe } \\
\text { getting vaccinated is smart. } \\
64 \% \text { believe vaccination is } \\
\text { safe. }\end{array}$ & $\mathrm{L}$ \\
\hline $\begin{array}{l}* * \text { Mayer } \\
2013[41]\end{array}$ & $\begin{array}{l}\text { C/S } \\
\text { Online } \\
\text { SAQ }\end{array}$ & $\begin{array}{l}\text { USA; boys } \\
9-26\end{array}$ & $\begin{array}{l}176 \text { boys } \\
15-17 \\
\text { years** } \\
\text { National } \\
\text { sample. } \\
\text { RR } 73 \%\end{array}$ & $\begin{array}{l}\text { V and } \\
\text { UV }\end{array}$ & online & $\begin{array}{l}\text { Assessed knowledge of HPV } \\
\text { only. } \\
40 \% \text { heard of HPV; } 15 \% \\
\text { heard of HPV, with low } \\
\text { knowledge. } 25 \% \text { heard of } \\
\text { HPV, high knowledge. }\end{array}$ & $\begin{array}{l}\text { Percentage willingness not } \\
\text { assessed, although perceived } \\
\text { likelihood of getting HPV was } \\
2.09 \text { on a } 4 \text { point scale ( } 1=\text { no } \\
\text { chance, } 4=\text { high chance) }\end{array}$ & $\begin{array}{l}\text { Perceived peer acceptance of } \\
\text { vaccine was } 3.06 \text { on } 5 \text { point } \\
\text { scale (1=strongly disagree, } \\
5=\text { strongly agree), } \\
\text { Anticipated regret if didn't } \\
\text { get HPV vaccine and later got } \\
\text { HPV infection was } 3.16 \text { on } 4 \\
\text { point scale (1= nothing at all, } \\
5=\text { a lot) }\end{array}$ & $\mathrm{H}$ \\
\hline \multicolumn{10}{|c|}{$\begin{array}{l}\text { ** Reiter et al., 2011; Moss et al., } 2015 \text { and Mayer et al., } 2013 \text { all report on data from the } 2010 \text { HPV Immunization in Sons (HIS) Study. Mayer used a subsample of boys aged } 15-1 \\
\text { years as their study focussed on sexual disinhibition, these items were not asked of younger sons. }\end{array}$} \\
\hline \multicolumn{10}{|l|}{ EUROPE } \\
\hline $\begin{array}{l}\text { Maier } \\
2015[42]\end{array}$ & $\begin{array}{l}\text { C/S } \\
\text { SAQ }\end{array}$ & $\begin{array}{l}\text { Romania; } \\
\text { no male } \\
\text { vaccine }\end{array}$ & $\begin{array}{l}524 \text { ( } 262 \\
\text { boys, } 262 \\
\text { girls) } \\
16-18 \text { years } \\
\text { Two schools } \\
\text { in Bucharest }\end{array}$ & UV & School & $\begin{array}{l}\text { Assessed knowledge of HPV } \\
\text { and knowledge of HPV } \\
\text { vaccine. } \\
17 \% \text { boys heard of HPV; } 8 \% \\
\text { boys heard of the vaccine. } \\
\text { Significantly lower than } \\
\text { girls. } \\
\text { No significant difference in } \\
\text { knowledge scores between } \\
\text { boys and girls. Only } 6.6 \% \\
\text { had high knowledge, } 60 \% \\
\text { fair knowledge, } 34 \% \text { low } \\
\text { knowledge. }\end{array}$ & $\begin{array}{l}\text { If they received more } \\
\text { information on vaccination, } \\
43 \% \text { of boys would be willing } \\
\text { to be vaccinated. }\end{array}$ & Lack of information & $\mathrm{M}$ \\
\hline
\end{tabular}




\begin{tabular}{|c|c|c|c|c|c|c|c|c|c|}
\hline $\begin{array}{l}\text { Hilton } \\
2013[43]\end{array}$ & $\begin{array}{l}\mathrm{C} / \mathrm{S} \\
\mathrm{FG}\end{array}$ & $\begin{array}{l}\text { Scotland; } \\
\text { no male } \\
\text { vaccine }\end{array}$ & $\begin{array}{l}59 \text { ( } 30 \text { boys, } \\
29 \text { girls) } \\
13-18 \text { years } \\
\text { Diverse } \\
\text { sample }\end{array}$ & UV & Comm & $\begin{array}{l}\text { Assessed HPV knowledge } \\
\text { via discussions on } \\
\text { awareness of disease, and } \\
\text { understanding of disease } \\
\text { process and symptoms } \\
\text { Boys demonstrated little } \\
\text { awareness of HPV, believed } \\
\text { it affected only females }\end{array}$ & Not examined. & $\begin{array}{l}\text { Viewed as a prevalent } \\
\text { infection and a serious } \\
\text { disease. } \\
\text { Fear of needles and pain. }\end{array}$ & \\
\hline $\begin{array}{l}\text { Samkang } \\
\text { e-Zeeb } \\
2013[44]\end{array}$ & $\begin{array}{l}\mathrm{C} / \mathrm{S} \\
\text { SAQ } \\
2011\end{array}$ & $\begin{array}{l}\text { Germany; } \\
\text { no male } \\
\text { vaccine }\end{array}$ & $\begin{array}{l}1148 \text { (632 } \\
\text { females and } \\
516 \\
\text { Males) } \\
12-20 \text { years } \\
\text { old } \\
\text { Bremen and } \\
\text { Bremerhaven } \\
\text { Northern } \\
\text { Germany } \\
\text { RR 28\% }\end{array}$ & UV & School & $\begin{array}{l}\text { Assessed knowledge of HPV } \\
\text { and knowledge of HPV } \\
\text { vaccine. } \\
\text { Significantly more females } \\
\text { than males had heard of } \\
\text { HPV (18 vs. } 8 \%) \\
15 \% \text { of boys aware that } \\
\text { HPV causes cervical cancer; } \\
9 \% \text { of boys aware of HPV } \\
\text { vaccination. }\end{array}$ & Not examined & Not examined & $\mathrm{M}$ \\
\hline $\begin{array}{l}\text { Stocker } \\
2013[45]\end{array}$ & $\begin{array}{l}C / S \\
S A Q \\
2010\end{array}$ & $\begin{array}{l}\text { Germany; } \\
\text { no male } \\
\text { vaccine }\end{array}$ & $\begin{array}{l}442 \text { ( } 238 \text { girls, } \\
204 \text { boys) } \\
13-19 \text { years } \\
\text { Berlin } \\
\text { RR } 59 \%\end{array}$ & $\begin{array}{l}60 \% \\
\text { girls V }\end{array}$ & School & $\begin{array}{l}\text { Assessed knowledge of HPV } \\
\text { only. } \\
\text { Boys showed same trend in } \\
\text { knowledge as unvaccinated } \\
\text { girls. Boys had less } \\
\text { knowledge than vaccinated } \\
\text { girls, but only slightly less } \\
\text { than unvaccinated girls. } \\
43.9 \% \text { knew HPV caused } \\
\text { cervical cancer and penile } \\
\text { cancer }\end{array}$ & Not assessed in boys & Not assessed in boys & $M$ \\
\hline $\begin{array}{l}\text { Forster } \\
2012[46]\end{array}$ & $\begin{array}{l}\text { C/S } \\
\text { SAQ }\end{array}$ & $\begin{array}{l}\text { England; } \\
\text { no male } \\
\text { vaccine }\end{array}$ & $\begin{array}{l}528 \text { boys } \\
16-18 \text { years } \\
\text { One school SE }\end{array}$ & UV & School & $\begin{array}{l}\text { Assessed knowledge of HPV } \\
\text { and knowledge of HPV } \\
\text { vaccine. }\end{array}$ & $\begin{array}{l}41 \% \text { willing to receive } \\
\text { vaccine. } \\
\text { Boys who were unsure }\end{array}$ & $\begin{array}{l}\text { To protect health. } \\
\text { Current sexual inactivity. }\end{array}$ & $\mathrm{M}$ \\
\hline
\end{tabular}




\begin{tabular}{|c|c|c|c|c|c|c|c|c|c|}
\hline & & & $\begin{array}{l}\text { England } \\
\text { RR 89\% }\end{array}$ & & & $52 \%$ boys aware of HPV & $\begin{array}{l}\text { whether to have the vaccine } \\
\text { were significantly less likely } \\
\text { to have heard of HPV ( } 44 \%) \\
\text { compared with boys who } \\
\text { intended }(63 \%) \text { or did not } \\
\text { intend }(58 \%) \text { to have it. }\end{array}$ & & \\
\hline $\begin{array}{l}\text { Sopracor } \\
\text { devole } \\
2012 \text { [47] }\end{array}$ & $\begin{array}{l}C / S \\
\text { SAQ } \\
2009\end{array}$ & $\begin{array}{l}\text { Italy; no } \\
\text { male } \\
\text { vaccine } \\
\text { Third year } \\
\text { of female } \\
\text { vaccine }\end{array}$ & $\begin{array}{l}1105 \text { ( } 476 \\
\text { males, } 629 \\
\text { females) } \\
13-23 \text { years } \\
\text { (mean } 15 \text { ) } \\
\text { One town NE } \\
\text { Italy } \\
\text { RR } 100 \%\end{array}$ & $\begin{array}{l}45.4 \% \\
\text { girls } \\
\text { vaccinat } \\
\text { ed }\end{array}$ & School & $\begin{array}{l}\text { Assessed knowledge of HPV } \\
\text { and knowledge of HPV } \\
\text { vaccine. } \\
51.3 \% \text { boys heard of HPV } \\
\text { (92.8\% girls) better } \\
\text { knowledge reported by } \\
\text { girls. Of those who were } \\
\text { aware of HPV, more girls } \\
\text { knew about the vaccine } \\
(94.5 \% \text { v } 71.3 \%)\end{array}$ & Not examined & Not examined & $M$ \\
\hline $\begin{array}{l}\text { Marek } \\
2011[48]\end{array}$ & $\begin{array}{l}C / S \\
S A Q\end{array}$ & $\begin{array}{l}\text { Hungary; } \\
\text { no male } \\
\text { vaccine }\end{array}$ & $\begin{array}{l}1769 \text { ( } 820 \\
\text { boys, } 949 \\
\text { girls) } \\
12-19 \text { years } \\
\text { National } \\
\text { sample } \\
\text { RR } 90 \%\end{array}$ & UV & School & $\begin{array}{l}\text { Assessed knowledge of HPV } \\
\text { and knowledge of HPV } \\
\text { vaccine. } \\
20 \% \text { primary school boys } \\
\text { and } 29 \% \text { secondary school } \\
\text { boys heard of HPV. Of } \\
\text { those who had heard of } \\
\text { HPV; } 45 \% \text { primary and } 47 \% \\
\text { secondary boys know HPV } \\
\text { linked to CC. } 27 \% \text { and } 34 \% \\
\text { aware of link to genital } \\
\text { warts. }\end{array}$ & $\begin{array}{l}60 \% \text { of boys would accept the } \\
\text { vaccine if it was free. }\end{array}$ & $\begin{array}{l}86 \% \text { believed in the } \\
\text { effectiveness of the vaccine. } \\
60 \% \text { primary and } 61 \% \\
\text { secondary boys would } \\
\text { request vaccine if it was free. } \\
40 \% \text { and } 35 \% \text { would pay for } \\
\text { vaccine. } \\
\text { Worries around side effects. }\end{array}$ & $\mathrm{H}$ \\
\hline $\begin{array}{l}\text { Pelucchi } \\
2010[49]\end{array}$ & $\begin{array}{l}\text { C/S } \\
\text { SAQ } \\
2008\end{array}$ & $\begin{array}{l}\text { Italy; no } \\
\text { male } \\
\text { vaccine } \\
\text { First year } \\
\text { of female } \\
\text { vaccine }\end{array}$ & $\begin{array}{l}\mathrm{M}=209 ; \mathrm{F}= \\
649 \\
14-20 \text { years } \\
\text { Milan, } \\
\text { northern Italy }\end{array}$ & UV & School & $\begin{array}{l}\text { Assessed knowledge of HPV } \\
\text { and knowledge of HPV } \\
\text { vaccine. } \\
\text { Males had less knowledge } \\
\text { of HPV ( } 72 \vee 51 \%) \text {, thought } \\
\text { it concerned them (only }\end{array}$ & $\begin{array}{l}68 \% \text { girls } \vee 40 \% \text { males said } \\
\text { they would undergo } \\
\text { vaccination. }\end{array}$ & $\begin{array}{l}\text { The students who were } \\
\text { aware that HPV could affect } \\
\text { them (felt at risk) were more } \\
\text { in favour of vaccination } \\
\text { regardless of whether or not } \\
\text { they were M or F }\end{array}$ & $\mathrm{M}$ \\
\hline
\end{tabular}




\begin{tabular}{|c|c|c|c|c|c|c|c|c|c|}
\hline & & & RR 79\% & & & $\begin{array}{l}26 \% \text { boys thought it did } \\
\text { concern them versus } 45 \% \\
\text { girls), the purpose of HPV } \\
\text { vac ( } 75 \text { v } 63 \% \text { of those who } \\
\text { had heard of HPV) }\end{array}$ & & & \\
\hline $\begin{array}{l}\text { Hoglund } \\
2009[50]\end{array}$ & $\begin{array}{l}\text { C/S } \\
\text { SAQ }\end{array}$ & $\begin{array}{l}\text { Sweden; } \\
\text { no male } \\
\text { vaccine }\end{array}$ & $\begin{array}{l}459 \text { ( } 209 \\
\text { boys, } 250 \\
\text { girls) } \\
15-20 \text { years } \\
\text { One town } \\
\text { RR } 80 \%\end{array}$ & UV & School & $\begin{array}{l}\text { Assessed knowledge of HPV } \\
\text { and knowledge of HPV } \\
\text { vaccine. } \\
5 \% \text { of total participants had } \\
\text { heard of HPV, } 1 \% \text { aware of } \\
\text { vaccine, } 2 \% \text { aware that } \\
\text { boys can contract HPV. } \\
\text { No difference between } \\
\text { boys and girls. }\end{array}$ & Not examined & Not examined & $M$ \\
\hline $\begin{array}{l}\text { Gottvall } \\
2009[51]\end{array}$ & $\begin{array}{l}\text { C/S } \\
\text { SAQ }\end{array}$ & $\begin{array}{l}\text { Sweden; } \\
\text { no male } \\
\text { vaccine }\end{array}$ & $\begin{array}{l}608 \text { ( } 347 \text { girls, } \\
261 \text { boys } \\
15-16 \text { years } \\
\text { RR } 86 \%\end{array}$ & UV & School & $\begin{array}{l}\text { Assessed knowledge of HPV } \\
\text { only } \\
\text { Virus } 9.6 \% \text { (boys only) }\end{array}$ & $\begin{array}{l}74.3 \% \text { boys would like } \\
\text { vaccine } \\
\text { High acceptance despite low } \\
\text { knowledge }\end{array}$ & $\begin{array}{l}76.3 \% \text { believe vaccine is } \\
\text { effective } \\
\text { Current sexual inactivity } \\
\text { Knowledge that vaccine } \\
\text { protected against GW } \\
\text { increased acceptance }\end{array}$ & $\mathrm{H}$ \\
\hline \multicolumn{10}{|l|}{ ASIA } \\
\hline $\begin{array}{l}\text { Hussain } \\
2014[52]\end{array}$ & $\begin{array}{l}\mathrm{C} / \mathrm{S} \\
\mathrm{SAQ} \text { and } \\
\mathrm{SSI}\end{array}$ & $\begin{array}{l}\text { India; no } \\
\text { male } \\
\text { vaccine }\end{array}$ & $\begin{array}{l}2500(1570 \\
\text { girls, } 930 \\
\text { boys) } \\
103312-18 \\
\text { years } \\
\text { Urban and } \\
\text { rural } \\
\text { RR } 96 \%\end{array}$ & UV & $\begin{array}{l}\text { School/ } \\
\text { Universi } \\
\text { ty }\end{array}$ & $\begin{array}{l}\text { Assessed knowledge of HPV } \\
\text { and knowledge of HPV } \\
\text { vaccine. } \\
\text { Very low level of } \\
\text { knowledge }-15 \% \text { of total } \\
\text { sample aware of cervical } \\
\text { cancer. Of } 930 \text { males, } 103 \\
\text { knew HPV caused cancer } \\
(11 \%), \text { and } 63 \text { knew of the } \\
\text { vaccine ( } 7 \%) \text {. } \\
\text { Female knowledge } \\
\text { significantly higher. }\end{array}$ & $\begin{array}{l}29.7 \% \text { boys would be willing } \\
\text { to have vaccine }\end{array}$ & $\begin{array}{l}\text { "a negative response was } \\
\text { documented with respect to } \\
\text { implementation of } \\
\text { vaccination } \\
\text { programme in India due to } \\
\text { adverse effects of vaccine } \\
\text { related deaths recently" }\end{array}$ & $\mathrm{L}$ \\
\hline
\end{tabular}




\begin{tabular}{|c|c|c|c|c|c|c|c|c|c|}
\hline $\begin{array}{l}\text { Tang } \\
2014[53]\end{array}$ & $\begin{array}{l}\mathrm{C} / \mathrm{S} \\
\mathrm{SAQ}\end{array}$ & $\begin{array}{l}\text { China; no } \\
\text { male } \\
\text { vaccine }\end{array}$ & $\begin{array}{l}848 \text { ( } 452 \text { girls, } \\
396 \text { boys) } \\
14-18 \text { years } \\
\text { RR } 94 \%\end{array}$ & UV & School & $\begin{array}{l}\text { Assessed knowledge of HPV } \\
\text { and knowledge of HPV } \\
\text { vaccine. } \\
\text { Virus } 10 \% \text {, vaccine } 9.1 \% \\
\text { Gender difference in } \\
\text { knowledge scores }\end{array}$ & Not examined & Not examined & $\mathrm{H}$ \\
\hline $\begin{array}{l}\text { Songthap } \\
2012[54]\end{array}$ & $\begin{array}{l}/ S \\
\text { SAQ }\end{array}$ & $\begin{array}{l}\text { Thailand; } \\
\text { no male } \\
\text { vaccine }\end{array}$ & $\begin{array}{l}644 \text { ( } 343 \text { girls, } \\
301 \text { boys). } \\
12-15 \text { years } \\
\text { Bangkok } \\
\text { RR } 80 \%\end{array}$ & UV & School & $\begin{array}{l}\text { Assessed knowledge of HPV } \\
\text { and knowledge of HPV } \\
\text { vaccine. } \\
\text { Vaccine } 60.18 \% \text { (boys only) } \\
80 \% \text { boys had knowledge of } \\
\text { HPV. No gender difference } \\
\text { in scores. }\end{array}$ & $\begin{array}{l}\text { Willingness to get vaccine } \\
25.3 \% \text { in favour, } 52.4 \% \\
\text { unsure, } 22.3 \% \text { against }\end{array}$ & $\begin{array}{l}\text { Availability, education, } \\
\text { efficacy } 37.2 \%\end{array}$ & $\mathrm{H}$ \\
\hline \multicolumn{10}{|l|}{ OCEANIA } \\
\hline $\begin{array}{l}\text { Zou } 2014 \\
{[55]}\end{array}$ & $\begin{array}{l}\text { C/S } \\
\text { SAQ } \\
2010- \\
2012\end{array}$ & $\begin{array}{l}\text { Australia; } \\
\text { female } \\
\text { only at } \\
\text { time of } \\
\text { study } \\
\text { [male } \\
\text { vaccine } \\
\text { 2013] }\end{array}$ & $\begin{array}{l}200 \text { MSM } \\
16-20 \text { years } \\
\text { Melbourne } \\
\text { RR? }\end{array}$ & UV & $\begin{array}{l}\text { Comm } \\
\text { and } \\
\text { other }\end{array}$ & $\begin{array}{l}\text { Assessed knowledge of HPV } \\
\text { and knowledge of HPV } \\
\text { vaccine. } \\
\text { High level of HPV } \\
\text { knowledge }\end{array}$ & $\begin{array}{l}\text { High acceptance - If vaccine } \\
\text { free, } 86 \% \text { willing to disclose } \\
\text { their sexuality to receive the } \\
\text { vaccine }\end{array}$ & $\begin{array}{l}80 \% \text { not willing to purchase } \\
\text { the vaccine because of its } \\
\text { cost. }\end{array}$ & $\mathrm{M}$ \\
\hline $\begin{array}{l}\text { Agius } \\
2010[56]\end{array}$ & $\begin{array}{l}C / S \\
\text { SAQ } \\
2008\end{array}$ & $\begin{array}{l}\text { Australia; } \\
\text { Female } \\
\text { vaccine at } \\
\text { time of } \\
\text { data } \\
\text { collection }\end{array}$ & $\begin{array}{l}1927 \text { ( } 793 \\
\text { boys, } 1134 \\
\text { girls) } \\
14-20 \text { years } \\
\text { Nationally } \\
\text { representative } \\
\text { RR } 66 \%\end{array}$ & UV & School & $\begin{array}{l}\text { Assessed knowledge of HPV } \\
\text { and knowledge of HPV } \\
\text { vaccine. } \\
19.2 \% \text { boys aware of virus } \\
\begin{array}{l}8.5 \% \text { boys aware of vaccine } \\
\text { availability }\end{array}\end{array}$ & Not examined & Not examined & $M$ \\
\hline
\end{tabular}




\begin{tabular}{|c|c|c|c|c|c|c|c|c|c|}
\hline \multicolumn{10}{|l|}{ AFRICA } \\
\hline $\begin{array}{l}\text { Poole } \\
2013 \text { [57] }\end{array}$ & $\begin{array}{l}\text { C/S } \\
\text { SSI } 2011\end{array}$ & $\begin{array}{l}\text { Mali; no } \\
\text { male } \\
\text { vaccine. } \\
\text { Prior to } \\
\text { HPV } \\
\text { vaccine } \\
\text { licensing }\end{array}$ & $\begin{array}{l}\text { adolescents: } \\
20 \text { ( } 12 \text { male) } \\
14 \text { years } \\
\text { Convenience } \\
\text { sample } \\
\text { RR } 98 \%\end{array}$ & UV & $\begin{array}{l}\text { in own } \\
\text { home }\end{array}$ & $\begin{array}{l}\text { Assessed knowledge of HPV } \\
\text { Low levels of knowledge in } \\
\text { both genders. }\end{array}$ & $\begin{array}{l}100 \% \text { said they'd be willing to } \\
\text { receive the vaccine (despite } \\
\text { low knowledge). }\end{array}$ & Vaccine price & $M$ \\
\hline
\end{tabular}

$\mathrm{C} / \mathrm{S}=$ cross-sectional; SAQ = self-administered questionnaire; YRBSS = The Youth Risk Behavior Surveillance System; V = vaccinated; UV = unvaccinated; $\mathrm{RR}=$ response rate; $\mathrm{NK}=$ not known; comm = community 
Table 2: Critical Appraisal of quantitative/mixed methods studies

\begin{tabular}{|c|c|c|c|c|c|c|c|c|c|c|c|}
\hline & 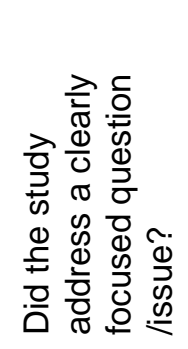 & 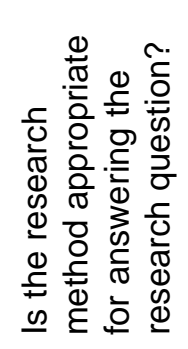 & 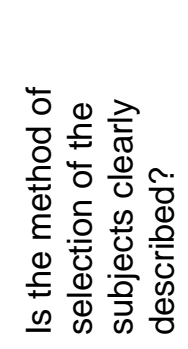 & 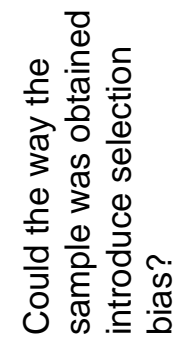 & 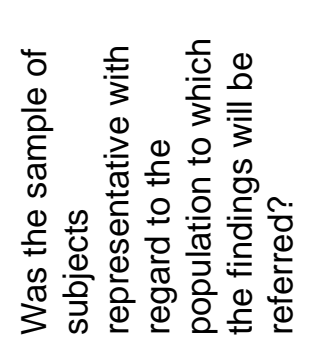 & 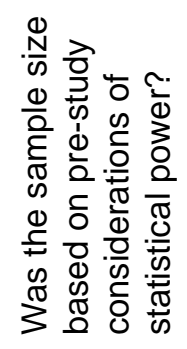 & 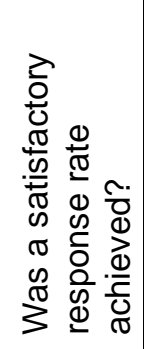 & 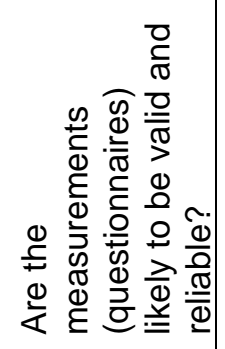 & 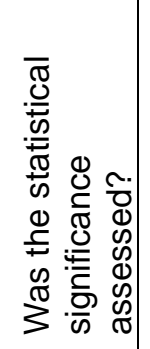 & 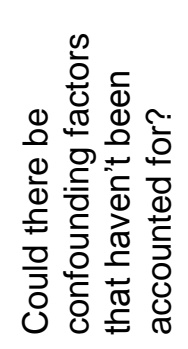 & 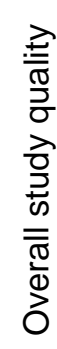 \\
\hline \multicolumn{12}{|l|}{ US } \\
\hline Bhatta 2015 & $\mathrm{Y}$ & $\mathrm{Y}$ & $\mathrm{Y}$ & $\mathrm{N}$ & $\mathrm{Y}$ & $\mathrm{N}$ & $\mathrm{Y}$ & $\mathrm{Y}$ & $\mathrm{Y}$ & $\mathrm{N}$ & $\mathrm{H}$ \\
\hline $\begin{array}{l}\text { Moss } \\
\text { 2015/Mayer } \\
\text { 2013/ } \\
\text { Reiter } 2011\end{array}$ & $\bar{Y}$ & $\bar{Y}$ & $\mathrm{Y}$ & $\mathrm{N}$ & $\mathrm{Y}$ & $\mathrm{N}$ & $\mathrm{Y}$ & $\bar{Y}$ & $\mathrm{Y}$ & $\mathrm{N}$ & $\mathrm{H}$ \\
\hline Shao 2015 & $\mathrm{Y}$ & $\mathrm{Y}$ & $\mathrm{N}$ & $\mathrm{Y}$ & $\mathrm{N}$ & $\mathrm{N}$ & $\mathrm{Y}$ & CT & $\mathrm{Y}$ & $\mathrm{N}$ & $\mathrm{L}$ \\
\hline $\begin{array}{l}\text { Gutierrez } \\
2013\end{array}$ & $\bar{Y}$ & $\mathrm{Y}$ & $\mathrm{N}$ & $\mathrm{Y}$ & $\mathrm{N}$ & $\mathrm{N}$ & CT & CT & $\mathrm{Y}$ & $\mathrm{N}$ & $L$ \\
\hline \multicolumn{12}{|l|}{ EUROPE } \\
\hline Maier 2015 & $\mathrm{Y}$ & $\mathrm{Y}$ & $\mathrm{Y}$ & $\mathrm{Y}$ & $\mathrm{N}$ & $\mathrm{N}$ & CT & $\mathrm{Y}$ & $\mathrm{Y}$ & $\mathrm{N}$ & $\mathrm{M}$ \\
\hline $\begin{array}{l}\text { Stocker } \\
2013\end{array}$ & $\mathrm{Y}$ & $\mathrm{Y}$ & $\mathrm{Y}$ & $\mathrm{Y}$ & $\mathrm{N}$ & $\mathrm{Y}$ & $\mathrm{Y}$ & $\mathrm{Y}$ & $\mathrm{Y}$ & $\mathrm{N}$ & $M$ \\
\hline $\begin{array}{l}\text { Samkange- } \\
\text { Zeeb } 2013\end{array}$ & $\mathrm{Y}$ & $\mathrm{Y}$ & $\mathrm{Y}$ & $\mathrm{N}$ & $\mathrm{Y}$ & $\mathrm{N}$ & $\mathrm{N}$ & CT & $\mathrm{Y}$ & $\mathrm{N}$ & $M$ \\
\hline Forster 2012 & $Y$ & $\mathrm{Y}$ & $\mathrm{Y}$ & $\mathrm{Y}$ & $\mathrm{N}$ & $\mathrm{N}$ & $\mathrm{Y}$ & CT & $\mathrm{Y}$ & $\mathrm{N}$ & $\mathrm{M}$ \\
\hline $\begin{array}{l}\text { Sopracordev } \\
\text { ole } 2012\end{array}$ & $\bar{Y}$ & $\mathrm{Y}$ & $\mathrm{Y}$ & $Y$ & $\mathrm{~N}$ & $\mathrm{~N}$ & $\mathrm{Y}$ & $\mathrm{Y}$ & $\mathrm{Y}$ & $\mathrm{N}$ & $\mathrm{M}$ \\
\hline Marek 2012 & $\mathrm{Y}$ & $\mathrm{Y}$ & $\mathrm{Y}$ & $\mathrm{N}$ & $\mathrm{Y}$ & $\mathrm{N}$ & $\mathrm{Y}$ & $\mathrm{Y}$ & $\mathrm{Y}$ & $\mathrm{N}$ & $\mathrm{H}$ \\
\hline $\begin{array}{l}\text { Pelucchi } \\
2010\end{array}$ & $\mathrm{Y}$ & $\mathrm{Y}$ & $\mathrm{Y}$ & $\mathrm{Y}$ & $\mathrm{N}$ & $\mathrm{N}$ & $\mathrm{Y}$ & $\mathrm{Y}$ & $\mathrm{Y}$ & $\mathrm{N}$ & $\mathrm{M}$ \\
\hline $\begin{array}{l}\text { Hoglund } \\
2009\end{array}$ & $\mathrm{Y}$ & $\mathrm{Y}$ & $\mathrm{Y}$ & $\mathrm{N}$ & $\mathrm{Y}$ & $\mathrm{N}$ & $\mathrm{Y}$ & CT & $\mathrm{Y}$ & $\mathrm{N}$ & $\mathrm{M}$ \\
\hline $\begin{array}{l}\text { Gottvall } \\
2009\end{array}$ & $\mathrm{Y}$ & $\mathrm{Y}$ & $\mathrm{Y}$ & $\mathrm{N}$ & $\mathrm{N}$ & $\mathrm{Y}$ & $Y$ & $Y$ & $\mathrm{Y}$ & $\mathrm{N}$ & $\mathrm{H}$ \\
\hline \multicolumn{12}{|l|}{ OCEANIA } \\
\hline Zou 2014 & $\mathrm{Y}$ & $\mathrm{Y}$ & $\mathrm{Y}$ & $\mathrm{Y}$ & $\mathrm{N}$ & $\mathrm{Y}$ & CT & CT & $\mathrm{Y}$ & $\mathrm{N}$ & $\mathrm{M}$ \\
\hline Agius 2010 & $\mathrm{Y}$ & $\mathrm{Y}$ & $\mathrm{Y}$ & $\mathrm{N}$ & $\mathrm{Y}$ & $\mathrm{N}$ & $\mathrm{Y}$ & $\mathrm{N}$ & $\mathrm{Y}$ & $\mathrm{N}$ & $M$ \\
\hline
\end{tabular}




\begin{tabular}{|c|c|c|c|c|c|c|c|c|c|c|c|}
\hline Poole 2013 & $\mathrm{Y}$ & $\mathrm{Y}$ & $\mathrm{Y}$ & $\mathrm{Y}$ & $\mathrm{N}$ & $\mathrm{N}$ & $\mathrm{Y}$ & $\mathrm{N}$ & $\mathrm{Y}$ & $\mathrm{N}$ & $\mathrm{M}$ \\
\hline \multicolumn{12}{|l|}{ ASIA } \\
\hline $\begin{array}{l}\text { Hussain } \\
2014\end{array}$ & $\mathrm{Y}$ & $\mathrm{Y}$ & $\mathrm{N}$ & CT & $\mathrm{N}$ & $\mathrm{N}$ & $\mathrm{Y}$ & CT & $\mathrm{Y}$ & $\mathrm{N}$ & $L$ \\
\hline Tang 2014 & Y & $\mathrm{Y}$ & $\mathrm{Y}$ & $\mathrm{N}$ & $\mathrm{Y}$ & $\mathrm{Y}$ & $\mathrm{Y}$ & $\mathrm{Y}$ & $\mathrm{Y}$ & $\mathrm{N}$ & $\mathrm{H}$ \\
\hline $\begin{array}{l}\text { Songthap } \\
2012\end{array}$ & $\mathrm{Y}$ & $\mathrm{Y}$ & $\mathrm{Y}$ & $\mathrm{N}$ & $\mathrm{N}$ & $Y$ & $\mathrm{Y}$ & $Y$ & $\mathrm{Y}$ & $\mathrm{N}$ & $\mathrm{H}$ \\
\hline
\end{tabular}

$\mathrm{Y}=$ Yes $\mathrm{N}=$ No $\mathrm{CT}=$ Can't tell 
Table 3: Critical appraisal of qualitative studies

\begin{tabular}{|c|c|c|c|c|c|c|c|c|c|c|}
\hline & $\begin{array}{l}\text { Cle } \\
\text { ar } \\
\text { ai } \\
\mathrm{m} ?\end{array}$ & $\begin{array}{l}\text { Qualitat } \\
\text { ive } \\
\text { method } \\
\text { appropr } \\
\text { iate? }\end{array}$ & $\begin{array}{l}\text { Approp } \\
\text { riate } \\
\text { design? }\end{array}$ & $\begin{array}{l}\text { Appropr } \\
\text { iate } \\
\text { recruitm } \\
\text { ent? }\end{array}$ & $\begin{array}{l}\text { Data } \\
\text { collecti } \\
\text { on } \\
\text { adequa } \\
\text { te? }\end{array}$ & $\begin{array}{l}\text { Researc } \\
\text { her } \\
\text { relation } \\
\text { ship }\end{array}$ & $\begin{array}{l}\text { Ethica } \\
\text { I } \\
\text { issues }\end{array}$ & $\begin{array}{l}\text { Data } \\
\text { anal } \\
\text { ysis }\end{array}$ & $\begin{array}{l}\text { Clear } \\
\text { state } \\
\text { ment } \\
\text { of } \\
\text { findin } \\
\text { gs? }\end{array}$ & Valuable? \\
\hline $\begin{array}{l}\text { Hilt } \\
\text { on } \\
201 \\
3\end{array}$ & $Y$ & $Y$ & $Y$ & $\begin{array}{l}\text { Y } \\
\text { Various } \\
\text { recruitm } \\
\text { ent } \\
\text { sources, } \\
\text { purposi } \\
\text { ve } \\
\text { samplin } \\
\text { g, } \\
\text { diverse } \\
\text { sample }\end{array}$ & $\begin{array}{l}\text { No } \\
\text { mentio } \\
n \text { of } \\
\text { data } \\
\text { saturati } \\
\text { on, } \\
\text { limited } \\
\text { justific } \\
\text { ation } \\
\text { for } \\
\text { focus } \\
\text { groups }\end{array}$ & $\begin{array}{l}\text { Not } \\
\text { discuss } \\
\text { ed }\end{array}$ & $\begin{array}{l}\text { Not } \\
\text { discus } \\
\text { sed }\end{array}$ & $Y$ & $\mathrm{Y}$ & $\begin{array}{l}\text { Limited } \\
\text { generalisa } \\
\text { bility. } \\
\text { Gave } \\
\text { suggestio } \\
\text { ns for } \\
\text { future } \\
\text { research. }\end{array}$ \\
\hline
\end{tabular}

$\mathrm{Y}=$ Yes $\mathrm{N}=$ No $\mathrm{CT}=$ Can't tell 